Kiyomitsu Yui

Kobe University
$316.344 .44(520)$

https://doi.org/10.18485/climb.2017.5.2.ch1

\title{
H.G.WELLS AND NAGAI KAFU; COMPARATIVE CIVILIZATIONS AND SCIENCE FICTION
}

\author{
Summary \\ The paper aims to explore differences / similarities in modernity in a comparative \\ civilizational perspective by contrasting two eminent modern writers, H.G. WELLS (from \\ 'Western' modern) and NAGAI Kafū (from Japanese modern). The comparison is about \\ the deeper layer of cultural settings rather than institutional surface, since these two \\ writers created the stories that are embedded to civilizational settings. \\ 1Constructing the Contrast \\ 2Contrasted De-construction \\ 3Science Fiction as a Creation of Cultural Narrative and an Expression \\ of Civilizational Setting (and not as a prophecy \\ of future technological development)
}

\section{Constructing the Contrast}

I have once touched upon already the contrast between NAGAI Kafü's Bokuto Kitan and H.G.WELLS' The Door in the Wall as a part of the arguments of comparative modernities and different societal configurations of the institutions among those different modernities (Yui Kiyomitsu, Ca'Foscari Japanese Studies 5, pp.31-48, 2017). In this paper it is explored to develop the contrast towards another orientation into the discussion of culture and / or science. Yet it seems that the paper still needs to explain first of all the basic stories and the background of the two novels. 
Bokuto Kitan is one of the masterpieces written by NAGAI Kafū (1879-1959), a famous, outstanding Japanese novelist in the late Meiji to Showwa period, and a son, one of the founding fathers of the Meiji regime, namely his father was high government official (Ministry of Education and Ministry of Home Affairs) and later, one of the successful economic giants of the regime. His family lineage can be traced back to Edo period (premodern Japan) as one of the feudal lords and other noble classes. In this sense, his family is a rare example that has been survived through the Restoration of Meiji fundamental transformation keeping their status as a noble class before and after the regime change. Kafū often is called as a 'writer of nostalgia', nostalgia for ruined good old days but he has a good reason to be so because of his family lineage. He went study abroad to the U.S.A and France for nearly five years in total and when he returned Japan the experience only let him rediscover the grace of good old Japan. As a person who knows what the 'Western' cities are like he described with nostalgia the ruined Japan destroyed by modernization, being as a man from noble family yet survived in the new regime, since his father actually was a successful big figure in Meiji Regime. His ambivalent attitude towards Edo (before modernization) came from all these complex cultural background he had as his fate.

Modernization process of Japan, the Meiji Restoration, was achieved mainly by lower-class samurai warriors who lived in peripheral area, remote feudal domains from center of Japan. Main figures in Meiji Regime were more or less came from those peripheral domains, country-side, though there were a few exceptions such as Nagai family. Comparing to the samurais in Tokugawa Shogunate central government namely those upper / noble class samurais, main officials in the Meiji Regime are more or less 'barbarous' in terms of cultural level. And actually these 'barbarians' destroyed good old cultures from Edo, pre-modern Japan, which had been crystalized in a highly sophisticated level after 260 years of peace period of time. Those country-men were more or less alien vis-a-vis highly sophisticated Edo cultures. Meiji Regime was established by these young, powerful, fresh, barbarians, but they were not necessarily good appreciator of old cultural achievement from Edo, as they were 'country-men.' Instead of the old Edo culture, young Meiji Regime strongly introduced the 'Western' civilization, on the rejected and ruined Edo they tried to estab- 
Култура и/или наука

lish Westernized new Japan. In this context, Japanese modernization also is heavily Westernization.

Kafū can appreciate these ruined cultures with nostalgia because of his family lineage (the family was far from barbarous), even though his father was on the side of this new, young, strong and barbarous Regime, and though he himself went study abroad and lived there in the USA and France for five years and appreciated great cultural and artistic achievements in the West. All these elements let him take quite an ambivalent attitude towards Edo (before modernization) culture, yet in a final stance, he took the side of ruined Edo rather than father's Meiji side.

Kafū's novel Bokuto Kitan consists of many different sorts of dual structure. First, it has a layer in which the ' $\mathrm{l}$ ' as a narrator/writer is wondering around the area called Bokuto (literary means the 'east of the river Sumida' which is a downtown area where the persons like Kafū scarcely tread) to obtain some materials for his novel entitled Runaway.

Therefore, the novel can be termed as a meta-novel since this structure is a novel in a novel. Also, as a different kind of layer, the ' $\mathrm{l}$ ' confesses that he has a tendency of having a double personality and discloses only one face of them. Yet another layer is a spatial double structure. 'I', as a successful writer who lives in a Western style mansion in uptown Tokyo, visits the labyrinth of narrow paths in the prostitution area in downtown Tokyo every day and spends a double life hiding in there. Here Kafū himself tries to construct the contrast between uptown Tokyo where successful Meiji officers and military personnel live in a Western style big mansions, and downtown Tokyo where ruined Edo remains in its narrow labyrinth-like passes with Japanese style small houses stand side by side where Kafū finds remainders of good old Edo atmosphere. Using this special double structure, special segregation in Tokyo Kafū and his leading figure can enjoy the both worlds simultaneously. 'I' spends a life of 'habitat segregation' (domain segregation) shuttling between the two spaces, and feels pleasure and nostalgia in hiding himself (running away) in this downtown labyrinth, which is a sort of enchanted garden for him. Kafū as a Japanese modern man, thus, experienced his double-faceted daily life in his way of life of 'habitat segregation.' The point here is that the 'domain segregation' is not just confined to the spatial ones but is also expressed in the people's mind-set which the societal value orientation, civilizational settings of 
Japan allows as double structure in this real world and its domain segregational arrangements in the mind-set even in the process of modernization.

Meanwhile the leading character of Wells' (1866-1946) The Door in the Wall is a parliament man of the British National Assembly who was brought up in a distinguished and rigorous family. One day he ran away on the way from the Parliament to home after attending an important session in the parliament. In this context, this is also a story of a runaway. Yet it appeared to be the case that the next day his body was found in a deep hole on the construction site of a street.

What happened?

The leading character of the novel, in his infancy, as a precocious and honour student raised in a rigorous family, he once lost his way in a London street. It happened when he escaped from his house, and he found the tempting door on the white wall for the first time in his life. Behind the door there was the 'enchanted garden' (Wells [1911]1974, 148), filled with happiness by every nostalgic / beautiful things, and he noticed immediately by instinct that once he entered in it his father got furious.

After the first encounter, he had several chances to have a glance at the door. A second chance came to him when he was fascinated by the play called "Discovering the North West Passage" with his friends. Who can be the first to discover the shortest route to reach the school? Like Kafü's ' $I$ ' tried to be deeply versed in every back lanes and secret passes in the downtown Tokyo, Wells' leading character tried to come back to the secret enchanted garden by exploring every byway in London. In the middle of the play, he found the door on the street where "some rather lowclass" (Wells [1911] 1974, 153) lives.

If he enters there, he will be late for school. He was an honour student. He thought that he could come back later and on that day he went straight ahead to school.

Even after he grew up and become a successful politician, he never forgot about the door on the wall. One day, on his way to the Parliament to vote on another important decision, he saw the door again. But if he had stayed, he would have been late for the vote. He chose the reality and the duty to vote, even though he felt as if he had left his heart behind. In the Parliament he told to the ministerial whip that he "made 
a great sacrifice" to which the whip replied that "they all have" (Wells [1911] 1974, 158). Now, he became a Cabinet minister and one evening on his way from Parliament to home he ran away. Perhaps he once again saw the door, and finally this time he got to enter into it. This is a story of a runaway in a Western modern, Great Britain. He could not spend a dual life of 'habitat segregation' such as Kafü's 'I' could manage and enjoy, and he had to disappear from "this grey world" (Wells [1911] 1974, 151) to choose the pleasure in another world.

The story seems to me a perfect description of what happens in the process of disenchantment of the world (Entzauberung der Welt, in Weber's term) in Western modern and what asceticism could mean in the process. Actually Jorge Luis Borges picked up this story and collected it in one of the series called La Biblioteca di Babele, edited by him, in 1980, as a volume 8 in the series. In the preface of the volume Borges wrote that this story of H.G. Wells seems nearly in line with his autobiography yet at the same it becomes an autobiography of everyone, all of us in our age (Luis Borges, 訳p.11, 1985, 国書刊行会 ).

By constructing the contrast between Kafū and Wells, what I am trying to suggest here is that, the process of modernization in the 'West' as viewed by Max Weber, a sociological point of view, and which is so significantly expressed in Wells' story, is in contrast to the case of Japanese modernization expressed in Kafü's story. The very key-term of Weber's sociology is that the entire process of human history is the process of rationalization namely the emancipation of the world from the enchanted (magic) gardens, the process he himself termed as 'dis-enchantment'. And the process is accelerated and up-graded in its quality in the process of modernization. According to Weber, the process of modernization namely that of 'dis-enchantment' by Protestantism and the process of rationalization should be the ones that are a methodological as well as a systematic reformation / rationalization of the mundane world as a whole controlled by a transcendental criterion. In other word this has been also termed as horro vacui in the Western aesthetics but in this context expressed in social space, namely nothing should be left intact, left blank.

This point was actually the focus of the debate between R.N.Bellah, another eminent sociologist and Japanologist in our age and Maruyama Masao, the specialist and the most eminent social scientist in Japan after WW II. Bellah argued that Japan had achieved some rationalization 
already in the pre-modern era, which resulted in Japan's rapid modernization. Against this assertion, Maruyama put forward some counter-arguments and then asked why the fomentation and explosion of irrational sentiments of Emperor regime emerged in the process of Japan's modernization which led to the many wars. Instead, isn't it the case that Japanese modernization was not the systematic reformation of the entire mundane world including the state, by the transcendental criterion of ultimate value, but was the conflation of spiritual and magical(irrational) authority of the Emperor and the mundane power of the state, thus of ultra-nationalism?

The rational bureaucracy already existed in pre-modern Japan, but on the other side, though, some hedonistic another-world always simultaneously existed in this mundane world. This was related to the logic and the psychology of the 'habitat segregation' (domain segregation) in the instrumental rationality and the irrational world of 'free and easy going' ('let joy be unconfined', according to a Japanese saying) that co-existed side by side. While the Western notion of history can be described as the drama of 'all or nothing', the drastic alteration through the struggle to death between orthodoxy and heterodoxy (therefore the historical 'development'), the case of Japan can be considered as the world of 'habitat segregation' - for example, almost every different kind of religion may coexist in 'peace'.

Weber's inner worldly asceticism is supposed to be the one that cannot stop in front of the iron wall of the segregated domain. The logic of domain segregation in Japan reveals the tendency of side-by-side co-existence of the separated domains of rigorism and arbitrariness within one personality, which can be mobilized and used by one situation (field) and another. Once permitted and tolerated, this exceptionally hedonistic domain cannot stop invading and differentiating (in a mathematical sense) into every aspect of social behaviour. It is obvious that this type of principle tolerance (admission) of exceptional domain in the value system directly contradicts the idea of systemic application of the Weberian "ethic of asceticism" (Maruyama [1958] 1996, 287-8).

Kafū enjoyed the opportunity of hiding and living in another world within this world, while the leading character of Wells' could not help disappearing from this world in order to enjoy that enchanted garden. Here we have the contrast between 'habitat segregation' and 'systematic ratio- 
Култура и/или наука

nalization' in the deeper layer logic of collectivity / individual formation in different civilizational settings.

\section{Contrasted De-construction}

To combine this issue of deeper layer of logic of the civilizational orientation with more institutional level of relational pattern of the three elements (individual, intermediate group and the state), we see not only the difference of patterns as such on that level, but also the mechanism according to which the pattern can be realized and emerge only within the more fundamental layer of civilizational logic. In the case of Japan, the ideal type of the relational pattern is exercised differently within each domain of rational / functional (public) and non-functional/non-rational (private) domains. We know that also in the Western configuration the difference between public and private is significant, but in the case of the 'West', there are an orientation towards one transcendental value (the Weberian ideal type of the modern) and diversifications stemmed from this fundamental orientation, while in the case of Japan this basic layer of value orientation per se can be different in each domain.

Thus, according to these different value orientations, different relational patterns of more visible and more surface institutions can be formed in each domain in Japan; arrangement of the social, the institutional patterns can be different according to different domains. In the more functional domains, such as samurai's official work place and time, the intermediate group incorporated into the state is dominant and even almost perfectly prevailing, while, within more non-functional/non-rational domains, this pattern of arrangements is sometimes totally irrelevant.

This combination with a deeper layered logic of 'habitat segregation,' (domain segregation) as the presupposition for collectivity/individual formation, can be the initial condition to consider Japanese modernization. The next focal issue is, however, how this initial condition has been transformed or not transformed in the second modernity, high-modernity, late-modernity or post-modernity (whatever you name it) of contemporary society both in Japan and the 'West'.

In case of Japan in its second modernity, the radicalization of the 'domain segregation' is taking place, and it leads to the more radicalized 
pattern of the fragmentation of daily life which resulted in the decentralization of the self that is one of the typical condition of 'post-modernity' so to speak. Yet as I mentioned, this is not actually a 'post' modernity in case of Japan, but continuation of Japanese modern and rather radicalization of that.

Meanwhile, in case of the 'West', transformation of modernity took place, that could also be understood as the breakdown of one transcendental God (universal one value orientation), again related to the post-modern discussion meaning fragmentation of ideas and decentralization of the self as well. Perhaps one of the bases of the popularity of Japanese cultural production such as pop culture (Anime, Manga) in the world lies in this 'similar' condition of fragmentation of daily life which has long-standing history and accumulation of experiences in the case of Japan. In this regard (and only in this sense), 'West' is finally catching up Japan, in terms of this post-modern type of debate, fragmentation of daily life and ideas, in the situation of the patch-work of different cultural elements and sectors.

This apparent 'similarity', however, is stemmed from quite different deeper civilizational settings. And this difference sometimes brings about significant results. For instance, when S. Huntington put Japanese civilization as an unique and distinct civilization which is not identical neither Chinese and nor Western, he touched upon the deeper civilizational settings, thus civilizational orientation that shapes its own structure of historical pass dependency.

\section{Science Fiction as a Creation of Cultural Narrative and an Expression of Civilizational Setting (and not as a prophecy of future technological development)}

Now the issue should be connected to the theme of culture and / or science more directly. To put it differently in this paper's context, it is the issue what about the connection with the (natural) science which is supposed to have one universal logic.

Civilizational orientation works like the 'switchman' who switches the railway points in the most critical, fundamental cross-points and on these switched, canalized railway, people's daily life goes (these are M. Weber's expression again). Weber delineate the issue by paraphrasing it 
into two elements; value-orientation and daily interests. Within the fundamental frame of value orientation people's daily interests take place. For example, by religious reasons for certain people to take properly processed food is a vital question, at the same time for other people outside of the religious range these kinds of food are meaningless and only the taste or nutritive facts matter. Meanwhile for the people on diet, for instance, the nutritive facts are the first concern. In these cases, religions and diet concern is from value orientation and under the frame of the orientation their interest, what kind of food they should take in their daily life goes.

To illustrate the relationship between civilizational orientation and (natural) science, perhaps one of the most relevant ways is take analogy of the case of science fiction. To do that let us call H.G. Wells again, he is as you know more famous for his works such as The Island of Dr. Moreau, Invisible Man, Time Machine, or if you like Jules Verne for 20,000 Leagues Under the Sea, and the 80 Days Around the World, the works called science fiction.

It seems to be the usual case that these genius writers are supposed to predict the progress of science and technology by their profound knowledge of science in combination with their great imagination. But in the article let me try to see it from a different angle even from an opposite direction.

We can suppose, as M. Weber suggested, even the progress of science and technology is intertwined with the civilizational orientation, and he used the metaphor of the 'switchman' of the railway, and on this switched orientation human activities including scientific progress can go. Great writers such as Wells and Verne as writers / artists imagined the progress from their deeper mind-set, from their deeper layer of civilizational orientation, and the scientists worked in the same age and after them, are from the same mind-set and could go on the same 'railway' in the deeper layer. Differently put, Wells or Verne did not predict the development of the technology by its inherent inner logic, rather the scientists and technicians can only imagine the same direction of invention as the writers, because they can work in the same civilizational orientation.

Now I hope that the points I am trying to make becomes a bit clearer; the sub-title of the article is Comparative Civilizations and Science Fic- 
tion and in the combination of the two, science fiction can be a metaphor to indicate the significance of the deeper layer of civilizational orientation, civilizational settings, indicating even so called scientific development or progress is the invention of the imagination from the civilizational orientations as shared with science fictions.

But one can argue that in case of NAGAI Kafū, he is not a writer of science fiction. Then, let me take an example of MISHIMA Yukio who is one of the most talented and eminent novelists after WWII in Japan although he is basically neither a science fiction writer but he has one very interesting piece of work which is to say the least become so close to a science fiction. The novel is entitled A Beautiful Star（美しい星） written in 1962.

This is a story of one family whose members believe themselves as space man. The father of the family believe himself that he is from Mars, mother is from Jupiter, daughter is from Venus, and a son is from Mercury. This is not exactly a science fiction, but science fiction-like novel. Also this is a story not about spaceman but about human who think of themselves as spaceman, but at the same time, this is not about psychoanalysis of their mental illness or accuse and claim of their false disguising as space man, the novel has nothing to do that. Rather in the story Mishima just leave their state of consciousness as spaceman, as it is, then he describes how the world can be seen from the viewpoint, how beautiful this star / planet Earth becomes, and how human activities on this Earth as a whole becomes crucially precious. This is a story of one family, one domestic world, say, one small cosmos but at the same time about entire universe, whole cosmos.

The whole point here is that the novel is based on the very identicalness (sameness or equality) of the two different attribute / property. Namely the father is a Martian and at the same time, is a human. Like, Kafū has double faceted mind-set in one man living in the two different worlds simultaneously in his daily life, living in a big Western style mansion, and in the downtown Tokyo, suspicious and narrow street of Japanese labyrinth, MISHIMA's family members, with exaggeration and extension, are human and spaceman at the same time.

One can continue the frame of contrast further; Dr. Moreau manipulates different species from a human's standpoint as a commander of all species, like one transcendental being, Invisible Man, once he became 
invisible, he is invisible everywhere, and once he fails to be invisible he became visible everywhere, and nowhere to escape from being visible, namely to hide himself being visible, Time Machine apparently presupposes the fundamental notion of time-arrow, namely linear time, thus linear history, and within this type of idea of time, leading figure can be back and forth on the time linearity ; all these reflect the deeper layer of 'Western' civilizational settings that can be in contrast to 'Japan.'

Thus, in contrast, Kafū and his novel's leading figure can be visible and invisible at the same time in his daily life, between the different segments of the worlds of down-town and up-town Tokyo, and members of MISHIMA's family can live in the world, where category $A$ is at the same time $B, A$ equals $B$. Based upon this seeming contradiction Japanese daily life exists, and this formation is stemming from its fundamental / deeper layer of civilizational settings.

There is a religious doctrine called Honjisuijakusetsu in Japan. This is to try to make a 'dictionary' to translate Buddhism into Shintoism and vice versa. In this doctrine, for instance, highly ranked divinity (Deity) in Shintoism such as Amaterasu is considered to be a transformation of Dainichnyorai in Buddhism. In this sense, these two Deities are 'identical' and the doctrine is to make a dictionary of correspondence of the identification, between each of these Deities in the two religious hierarchies. Can one imagine that one particular divinity (Deity) is identical with another Deity / God in another different religion? (I am not talking about one transcendental God which is not the issue of identification but the contestation around appropriation of one universal God). Here we have needless to say the issue of syncretism, but if the term syncretism connote the meaning of the creation of the third emergent property resulted from the synthesis of the two different elements, it is not the case in this doctrine of Honjisuijakusetsu.

Rather, the article should make yet another point to be mentioned; these doctrines of identification, equality of different attribution is not an effort of making an integrated different cultures into one systemic entity according to one transcendental criterion. Instead, this is a sort of method to leave different cultures as they are, and not to clash with each other. This is to make a map to understand the difference in relational manner, trying not to synthesize them into higher dimension, but just leave them as they are, in order to switch the different worlds as quickly and smoothly as possi- 
ble, referring to the 'dictionary'. Thus for instance Japanese do their funeral ceremony in accordance to Buddhist form, wedding to Christian form, and New Year's and other celebrative occasions to Shintoism. They co-exist in performance in different social domains side by side peacefully.

The article has been touching upon the 'habitat segregation' or domain segregation, the term itself can be interpreted as a very conservative narrative, or could be liberal ones, but the intension of the article has nothing to do with these political narratives. The article is trying to indicate two things; First, difference of Japanese civilization from the 'Western' one in its deeper layers, in order for us to understand each other more deeper level. Second, also trying to make it relevant to contemporary world situation. Namely one of the ways of understanding other civilizations, to coexist with other civilizations side by side in this globalized world, and to avoid the clash of civilizations, and the possibilities of Japanese civilization in that trials, in its all the deficits and virtues, if there are any.

\section{Bibliography}

Appadurai, Arjun (1996). Modernity at Large-Cultural Dimensions of Globalization. Minneapolis; London: University of Minnesota Press.

Beck, Ulrich (2003). "Living Your Own Life in a Runaway World. Individualization, Globalization and Politics". Robertson, Roland; White, Kathleen (eds.). Globalization. Critical Concepts in Sociology, vol. 4. London; New York: Routledge, 272-80.

Beck, Ulrich (2008). What is Globalization? Transl. by P. Camiller. Cambridge (UK): Polity Press.

Beck, Ulrich; Beck-Gernsheim, Elisabeth (2002). Individualization. Institutionalized Individualism and its Social and Political Consequences. London: Sage Publications.

Bellah, Robert (1957). Tokugawa Religion. New York: Free Press.

Bellah, Robert (1963). "Reflections on the Protestant Ethic Analogy in Asia". Journal of Social Issues, 19, 52-60.

Berger, Peter L. (1967). The Sacred Canopy. Elements of a Sociological Theory of Religion. Garden City, N.Y. : Doubleday.

Coleman, James (1988). "Social Capital in the Creation of Human Capital". American Journal of Sociology, 94, 95-120.

Eisenstadt, Shmuel N. (2002). "Multiple Modernities". Eisenstadt, Shmuel N. (ed.). Multiple Modernities. New Brunswick: Transaction Publishers, 1-29.

Eisenstadt, Shmuel N. (2003). "Multiple Modernities in an Age of Globalization".

Eisenstadt, Shmuel N. (ed.). Comparative Civilizations and Multiple Modernities, vol. 2. Leiden: Brill, 519-33. 
Култура и/или наука

Hannigan, John A. (1995). Environmental Sociology. A Social Construction Perspective. London; New York: Routledge.

Hasegawa Yoshikazu (1989). "Nicchū Hikaku Kōzōron" (Comparative social structure of Japan and China). Sociological Review of Kobe University, 6, 1.

Koto Yosuke (1999). "Borantia katsudō to shimin undō" (Volunteer Activities and Civil Movement). Sociological Review, 6, 135-41.

Maruyama Masao [1958] (1996). "Bela Tokugawa jidai no shūkyō ni tsuite” (On Bellah's Tokugawa Religion). Kokkagakkaizasshi, 72(4). Reprinted: Maruyama Masao Shu (Collected Papers of Maruyama), vol. 7. Tōkyo: Iwanami shoten, 253-89.

Maruyama, Masao (1965). "Various Patterns of Individuation”. Jansen, Marius B. (ed.), Changing Japanese Attitude Toward Modernization. Princeton: Princeton University Press, 489-531.

Maruyama, Masao (1998). Collected Papers of Maruyama's Lectures, vol. 4. Tōkyō: University of Tokyo Press.

Mishima Yukio (1962). Utsukusii Hoshi (Beautiful Star).

Mizubayashi Hyo (2002). "Genkei (Koso) ron to kodai seijisiso ron" (Arguments on Prototype and Ancient Political Thought). Maruyama Masao Ron (Arguments on Maruyama). Tōkyō: Perikan Press.

Nagai Kafū (1937). Bokuto Kitan. Tōkyō: Iwanami Press.

Nozawa Shinji (2006). "Jō. Nettowaku genshō to shite no shakai" (Introduction. Society as Network Phenomena). Readings Network Theories, Tōkyō: Keiso Press.

Sakuta Kei'ichi (1967). Haji no bunka saikō (Culture of Shame Reconsidered). Tōkyō: Chikuma Shōbo.

Sassen, Saskia [1999] (2003) "Embedding the Global in the National". Robertson, Roland; White, Kathleen E. (eds.), Globalization. Critical Concepts in Sociology. London; New York: Routledge, 177-88.

Sato Yoshiyuki (2003). "Kōkyōsei no kōzō tenkan to asoshieshon kakumei" (Public Structural Transformation and Association Revolution). Shimin shakai to hihanteki kōkyōsei (Civil Society and Critical Public Sphere). Tōkyō: Bunshin-Do Press, 3-25.

Tominaga Ken'ichi (1984). "Gendai no shakaigakusha” (Contemporary Social Scientists). Jinrui no chiteki isan (Human Intellectual Heritage). Tōkyō: Kodansha Press, 79.

Wells, H.G. [1911] (1974). "The Door in the Wall". The Complete Short Stories. London: Ernest Benn Limited; St Martin's Press.

Yui, Kiyomitsu (1994). "Theories on Modernization of Japan Today" [online]. International Journal of Japanese Sociology, 3, 45-57. URL http:// onlinelibrary.wiley.com/ doi/10.1111/ijjs.1994.3.issue-1/issuetoc (2017-04-04).

Yui, Kiyomitsu (2006). "Theories of Comparative Modernization and Glocalization" [online]. How Is the Theory Formation Possible, special issue, Japanese Sociological Review, 57(1), 125-42. URL https://www. jstage.jst.go.jp/article/ jsr1950/57/1/57_1_125/_pdf (2017-04-04).

Yui, Kiyomitsu (2009). “Multiple Second Modernities under Glocalization. Individual, Intermediate Group, and the State" [online]. Globalization

Reconsidered, special issue, Japanese Sociological Review, 60(3), 330-47. URL https:// www.jstage.jst.go.jp/article/jsr1950/57/1/57_1_125/_pdf (2017-04-04). 


\section{Кијомицу Јуи}

Универзитет у Кобеу

\section{Х. Џ. ВЕЛС И НАГАИ КАФУ; УПОРЕДНЕ ЦИВИЛИЗАЦИЈЕ И НАУЧНА ФАНТАСТИКА}

\section{Сажетак}

Рад има за циљ да истражи аналитички оквир и његове основне премисе за разматрање ситуације у којој се данашња друштва као вишеструке друге модерности налазе под утицајем глокалокализације и бави са Јапаном као студијом случаја. У раду се анализирају различити обрасци односа између појединца, посредничке групе и државе у сваком региону/локалном подручуу и прати се трансформација тих образаца у савременом друштву. Понекад је структурална напетост својствена модерном друштву између традиционалних и у већој мери „уговорних“ елемената након модерне изражена у институционалним обрасцима односа између појединца, посредничке групе и државе у свим областима. У савременом друштву, које представља доба вишеструких других модерности, релациони образац је изражен у конфигурацији индивидуалности (а не појединца), посредничких мрежа (а не посредничке групе) и државе која је у процесу трансформације (не само државе). Како бисмо изучили особеност сваког локалитета кроз плуралистичку призму, морамо узети у обзир не само институционалну структуру ова три фактора, већ и много фундаменталнију логику формирања колективитета/појединца у сваком друштву о којем је реч. Рад се бави овом проблематиком кроз анализу дела Нагаи Кафуа и Х. Џ. Велса. Приликом истраживања поменуте проблематике, рад се фокусира на савремени Јапан, који нуди пример случаја вишеструке друге модерности под утицајем глокалокализације, а на основу посматрања јапанске историјске и културне посебности.

Кључне речи: вишеструке модерности, глокализација, посредничка група. 